\title{
Patterns of Mammography, Pap Smear, and Colorectal Cancer Screening Services Among Women Aged 45 and Over
}

by Yelena Gorina M.P.H., M.S., and Nazik Elgaddal, M.S.

\section{Abstract}

Background - Regular screening tests can lead to early detection of breast, cervical, and colorectal cancers, when treatment is likely to be more effective. This study examines and compares sociodemographic, health status, and health behavior patterns of screening for breast cancer, cervical cancer, and colorectal cancer among women aged 45 and over in the United States.

Methods - This study is based on data from the 2015 and 2018 National Health Interview Surveys. Women were considered to have received colorectal cancer screening if they reported having one of the following: a) report of a home fecal occult blood test (FOBT) in the past year, b) sigmoidoscopy procedure in the past 5 years with FOBT in the past 3 years, or c) colonoscopy in the past 10 years. Women were considered to have received breast cancer screening if they had a mammogram within the past 2 years. Women were considered to have received cervical cancer screening if they reported having a Pap smear in the past 3 years. Cancer screening was analyzed by sociodemographic, health status, health behavior, and health care use characteristics.

Results-Among women aged 45 and over, higher percentages of screening were associated with higher socioeconomic status, being married or living with a partner, and healthy behaviors such as not smoking, participating in physical activity, and receiving a flu shot.

Conclusion-Differences in screening identified in this study are generally consistent with previous studies on screening for colorectal, breast, and cervical cancers for women at average risk and within the age groups recommended for screening. The results of this study support other findings showing the persistence of disparities in cancer screening among women aged 45 and over according to most of the selected characteristics regardless of recommended age of screening.

Keywords: breast cancer $\bullet$ cervical cancer $\bullet$ disparity $\bullet$ testing $\bullet$ women's health $\bullet$ National Health Interview Survey

\section{Introduction}

For more than 3 decades, cancer has been the leading cause of death among women aged 45-64 and the second leading cause of death among women aged 65 and over $(1,2)$. Regular screening tests may detect breast, cervical, and colorectal cancers early, when treatment is likely to be more effective (3-9). Screening recommendations vary by age for women with average risk of developing these types of cancer.

Colorectal cancer (CRC) screening tests or procedures are used to detect polyps, abnormal cell growth, lesions, and other gastrointestinal conditions, including colon cancer. These tests may include home fecal occult blood tests (FOBT), sigmoidoscopy, or colonoscopy, which can also be used to remove precancerous or malignant polyps. The time interval between screenings varies depending on the type of test as well as individual risk factors and screening history. The U.S. Preventive Services Task Force (USPSTF) recommends screening adults with average risk of CRC starting at age 50 and continuing until age 75 using FOBT, sigmoidoscopy, colonoscopy, or another testing strategy. These recommendations are being updated (10). For adults aged 76-85,

\section{U.S. DEPARTMENT OF HEALTH AND HUMAN SERVICES Centers for Disease Control and Prevention National Center for Health Statistics}


USPSTF recommends that physicians determine the need for screening on an individual basis, taking into account the patient's overall health and screening history $(10,11)$. Current USPSTF draft recommendations include screening for colorectal cancer in adults aged 45-49 (12).

A mammogram is an $\mathrm{x}$-ray image of the breast used to detect irregularities in breast tissue that can be a sign of cancer. USPSTF recommends a biennial (every other year) mammogram starting at age 50 through 74 for women with average risk of breast cancer and advises determining the need for mammogram screening in women aged 40-49 on an individual basis. $(13,14)$.

A Pap smear (also known as a Papanicolaou smear or Pap test) is a microscopic examination of cells scraped from the cervix that is used to detect cancerous or precancerous conditions of the cervix. Current USPSTF recommendations, which apply to women at average risk of cervical cancer, call for Pap smear screening every 3 years for women aged 21-65, or a combination of Pap smear and human papillomavirus, or HPV, testing every 5 years for women aged $30-65(15,16)$. USPSTF recommends against Pap smear screening for women who have had a hysterectomy with the cervix removed and no history of high-grade precancerous lesions or cervical cancer.

Screening for women who are at high risk of developing breast, cervical, or colorectal cancer depends on clinical considerations for the specific cancer type; this decision should be made on an individual basis $(10,13,15,17)$.

Regardless of age, Medicare Part B covers all costs for screening procedures for breast, cervical, and colorectal cancers among Medicare beneficiaries aged 65 and over (18). Coverage of preventive services by private insurance and state Medicaid expansion programs under the Affordable Care Act, or ACA, is governed by recommendations from USPSTF and the Health Resources and Services Administration. Under these recommendations, private group and individual insurance plans and state Medicaid expansion programs are required to cover at no cost: a) screening mammography at least every 2 years and as frequently as once per year for women aged 40-74 with an average risk of breast cancer, and b) screening for cervical cancer every 3 years starting at age 30 (19). Coverage for CRC screening by private insurance and state Medicaid expansion programs varies by insurance plan and type of test (20-22).

The Healthy People initiative uses data from the National Health Interview Survey (NHIS) (23) to assess disparities in CRC screening among adults aged 50-75, breast cancer screening among women aged 50-74, and cervical cancer screening among women aged 21-65 (24-26). Other studies have assessed disparities in cancer screening (27-31) within age groups generally consistent with USPSTF recommendations for women at average risk of specific cancers.

This report assesses differences in screening for colorectal, breast, and cervical cancers by demographic and socioeconomic characteristics, health status, behavioral factors, and health care utilization among noninstitutionalized civilian women aged 45 and over.

\section{Methods}

\section{Data source and population}

NHIS is a cross-sectional household survey on the health of the civilian noninstitutionalized U.S. population conducted by the National Center for Health Statistics (NCHS). Data are collected annually through a personal household interview conducted by specially trained interviewers (23). NHIS consists of a core questionnaire that remains largely unchanged from year to year, and supplemental questionnaires that may vary from year to year. Up until the 2019 NHIS, the core consisted of four main components: Household Composition, Family Core, Sample Child Core, and Sample Adult Core.

In 2015 and 2018, NHIS supplementary questionnaires included questions on cancer screening based on USPSTF recommendations. Women aged 40 and over were asked about CRC screening, women aged 30 and over were asked about mammography, and women aged 18 and over were asked about cervical cancer screening. In this study, women aged 45-64 were analyzed separately from women aged 65 and over due to age-related influence on screening associated with Medicare eligibility among women aged 65 and over $(32,33)$.

Women were considered to have received $\mathrm{CRC}$ screening if they reported one of the following by the time of the NHIS interview: a) FOBT in the past year, b) sigmoidoscopy procedure in the past 5 years with FOBT in the past 3 years, or c) colonoscopy in the past 10 years. Women were considered to have received breast cancer screening if they reported a mammogram within the past 2 years, and cervical cancer screening if they reported having had a Pap smear within the past 3 years.

Data for 2015 and 2018 were combined to increase reliability of the estimates. Findings are based on face-to-face interviews with 19,822 civilian, noninstitutionalized women aged 45 and over, including 10,670 women aged 45-64 (6,185 women in 2015 and 4,485 women in 2018), and 9,152 women aged 65 and over (4,904 women in 2015 and 4,248 in 2018). The response rate for the Sample Adult component was 55.2\% in 2015 and $53.1 \%$ in 2018. Missing data on screening ranged from $3 \%$ to $9 \%$.

\section{Measures}

Race and Hispanic origin were recoded combining ethnicity (Hispanic or Latino or not Hispanic or Latino) and race categories (white, black, or Asian), as reported by the NHIS respondent. Persons of Hispanic origin may be of any race. Level of education was recoded as a dichotomous variable with the values of a) high school or less (11th grade or less, 12th grade with diploma, high school graduate, or GED), and b) some college or more (some college with no degree, associate's degree, or college graduate degree or higher). Poverty status was determined using NHIS imputed personal earning and income files (34) and defined as a dichotomous variable with the values of a) less than $200 \%$ poverty level and b) $200 \%$ or more above poverty level. Percentage of poverty level was calculated using the ratio of family income to poverty level income (35). Marital status was recoded as a) married (married or living with a partner) and 
b) not married (never married, widowed, separated, or divorced). Among women aged 45-64, health insurance status was recoded into two categories: a) insured, for persons covered by private insurance, Medicare, Medicaid, Children's Health Insurance Program, state-sponsored or other government-sponsored health plans, or military plans; and b) uninsured, for persons with none of these insurance types or with only Indian Health Service coverage. Estimates by insurance status were not shown for women aged 65 and over because more than $99 \%$ of them were insured, with the majority (95\%) of women insured by Medicare. Location of residence was categorized as a) metropolitan statistical area (MSA) or b) non-MSA, as defined by the Office of Management and Budget and applied to U.S. Census Bureau data (36).

Health status was measured by asking the family respondent about their health or the health of a family member: "Would you say [person's] health in general is excellent, very good, good, fair, or poor?" and combined in a dichotomous variable with the values of a) excellent, very good, or good; and b) fair or poor. The number of selected chronic conditions was calculated based on positive responses to the following questions: "Have you ever been told by a doctor or other health professional that you had: a) cancer or a malignancy of any kind; b) chronic obstructive pulmonary disease, or COPD; c) diabetes (other than during pregnancy); d) heart condition (coronary heart disease, angina, heart attack, or any other kind of heart disease); e) asthma; f) stroke; or g) hypertension?" and "During the past 12 months, have you been told by a doctor or other health professional that you had weak or failing kidneys (excluding kidney stones, bladder infections or incontinence)?" The number of chronic conditions was shown as a) none, b) one, c) two, or d) three or more (up to eight conditions). The answer to the question about ever having been diagnosed with cancer was also used to calculate cancer history as a dichotomous variable with the values of a) ever had cancer and b) no history of cancer. A dichotomous variable for history of hysterectomy was based on the question, "Have you had a hysterectomy?"
Current, past (former), and never cigarette smoking was assessed by respondent answers to a series of questions. Women who did not currently smoke and had never smoked 100 cigarettes were categorized as never smokers, and those who had smoked more than 100 cigarettes in their lifetime were defined as current cigarette smokers if they reported smoking every day or some days, or as former smokers otherwise. The measure of leisure-time physical activity is based on the federal 2008 Physical Activity Guidelines for Americans and was defined as participation in a) any physical activity if a person reported at least 150 minutes per week of moderate-intensity or 75 minutes per week of vigorous-intensity aerobic physical activity (or an equivalent combination of moderate- and vigorous-intensity aerobic activity) or muscle-strengthening activities at least twice per week (37) or b) none, otherwise.

Influenza vaccination was determined as a dichotomous variable with the values of a) yes, if a respondent reported receiving a flu shot or vaccine sprayed in the nose by a doctor or other health professional during the past 12 months, or b) no, otherwise. Frequent health care utilization was defined as a) yes, if a respondent reported seeing a doctor or other health care professional at a doctor's office, a clinic, an emergency room, or some other place (not including visits during overnight hospital stays) 10 or more times in the past 12 months, or b) no, otherwise.

\section{Data analysis}

Point estimates, standard errors, and $95 \%$ confidence intervals for the percentage of women screened and prevalence ratios were calculated using NHIS Sample Adult weights and adjusted for the complex sample design of NHIS using SUDAAN software (38). The reliability of survey percentage estimates was assessed based on the NCHS Data Standards for Proportions using a method based on the Clopper-Pearson confidence interval adapted for complex surveys by Korn and Graubard to determine if the estimate is unreliable and should be suppressed (39). The Mantel-Haenszel test was used to evaluate prevalence ratios. The $95 \%$ confidence intervals were also calculated. Estimates for women aged 65 and over were age adjusted. Differences between survey estimates were tested for statistical significance using a two-tailed $t$ test with a significance level of 0.05 . In describing the results, terms such as "higher than" and "lower than" indicate a statistically significant difference at the 0.05 level. The significance level of three or more pairwise difference tests was adjusted for multiple comparisons using the Bonferroni method. For each measure, the calculation of estimates excluded sample adults with missing information for relevant questions. Weighted estimates in this report are representative of civilian noninstitutionalized U.S. women aged 45 and over.

\section{Results}

Numbers and percentages of the study population by selected demographic and socioeconomic characteristics, health status, health behavior categories, and health care utilization are shown in Table 1.

\section{Cancer screening by sociodemographic characteristics}

As shown in Figure 1, the percentage of women receiving screening for CRC increased from $34.0 \%$ among those aged $45-54$ to $72.4 \%$ among women aged 65-74, and decreased to $47.0 \%$ among those aged 85 and over. About $70 \%$ of women in age groups 45-54, 55-64, and 65-74 reported receiving screening for breast cancer, and the percentage decreased to $31.3 \%$ among women aged 85 and over. Prevalence of screening for cervical cancer decreased with age, from $78.3 \%$ among women aged $45-54$ to $13.7 \%$ among those aged 85 and over.

\section{Women aged 45-64}

Among women aged 45-64, 50.1\% reported receiving CRC screening, 70.7\% breast cancer screening, and $73.5 \%$ cervical cancer screening, while $11.1 \%$ did not receive screening for any of the three cancer types (Table 2). Screening for 
Figure 1. Percentage of colorectal, breast, and cervical cancer screening among women aged 45 and over, by age: United States, 2015 and 2018

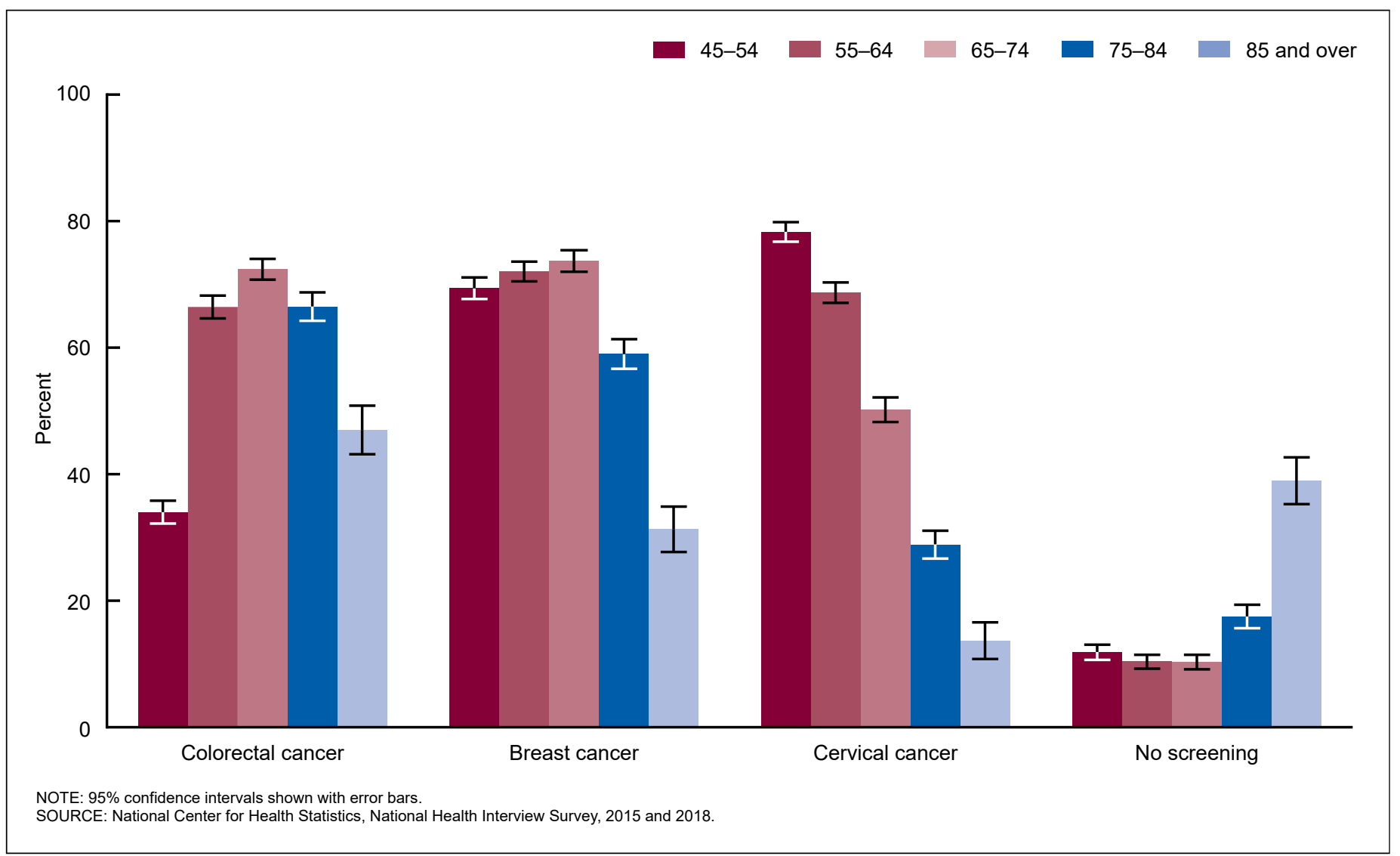

CRC was nearly two times higher among women aged 55-64 (66.4\%) compared with women aged 45-54 (34.0\%), while the percentages reporting screening for breast cancer were similar $(72.1 \%$ and $69.4 \%$, respectively). However, cervical cancer screening was lower among women aged 55-64 (68.7\% compared with $78.3 \%$ among women aged 45-54). The percentage of women reporting screening for CRC and breast cancer was higher among non-Hispanic white (53.8\% and $71.7 \%$ ) and non-Hispanic black (48.9\% and $72.9 \%$ ) women compared with non-Hispanic Asian (39.8\% and 67.0\%) and Hispanic (37.6\% and $66.3 \%$ ) women. The percentage receiving cervical cancer screening was similar by race and Hispanic origin (Figure 2). Hispanic and non-Hispanic Asian women were about 1.3 times more likely not to receive screening for any of the three cancers. Women in this age group with some college or more were about 1.2 times more likely to receive screening for each of the three cancers compared with women with less education, and were less likely to not receive screening for any of the three cancers (8.8\% compared with $15.4 \%)$. Women with family income $200 \%$ or more above the poverty level were 1.2 to 1.3 times more likely to report any of the three cancer screenings $(52.9 \%$ for CRC; $74.9 \%$ for breast; and $77.2 \%$ for cervical) compared with women with lower family income $(41.9 \%$ for CRC; $58.3 \%$ for breast; and $62.8 \%$ for cervical) (Figure 3). Women who were married or living with a partner were 1.1 times more likely to report screening for each of the three cancers compared with single or widowed women. Insured women were 2.2 times more likely to be screened for CRC (52.7\%), 2.0 times more likely to be screened for breast cancer $(73.8 \%)$, and 1.4 times more likely to be screened for cervical cancer $(75.4 \%)$ compared with uninsured women $(23.7 \%, 36.8 \%$, and $53.6 \%$, respectively), while uninsured women were 3.6 times more likely than insured women to not receive screening for any of the three cancers $(33.1 \%$ compared with 9.1\%) (Figure 4). Women living outside of an MSA were more likely to not be screened for any of the three cancers $(16.7 \%$ compared with $10.2 \%$ among women living in an MSA), although the percentages for screening for each of the three cancers were similar by MSA status.

\section{Women aged 65 and over}

Among women aged 65 and over, $67.2 \%$ had received CRC screening, $63.3 \%$ had received breast cancer screening, and $38.1 \%$ had received cervical cancer screening, while 16.4\% had not received screening for any of the three cancers (Table 3). Screening for all cancers was lower among women aged 75-84 and 85 and over compared with women aged $65-74$. The percentage of no screening was 1.7 and 3.8 times higher for women aged 75-84 (17.5\%) and 85 and over $(39.0 \%)$ compared with women aged 65-74 (10.3\%). Compared with Hispanic women, non-Hispanic Asian women were less likely to report all three screening types. Non-Hispanic black (69.2\%) and non-Hispanic white $(68.7 \%)$ women were more likely to report CRC screening but about as likely 
Figure 2. Percentage of colorectal, breast, and cervical cancer screening among women aged 45-64, by race and Hispanic origin: United States, 2015 and 2018

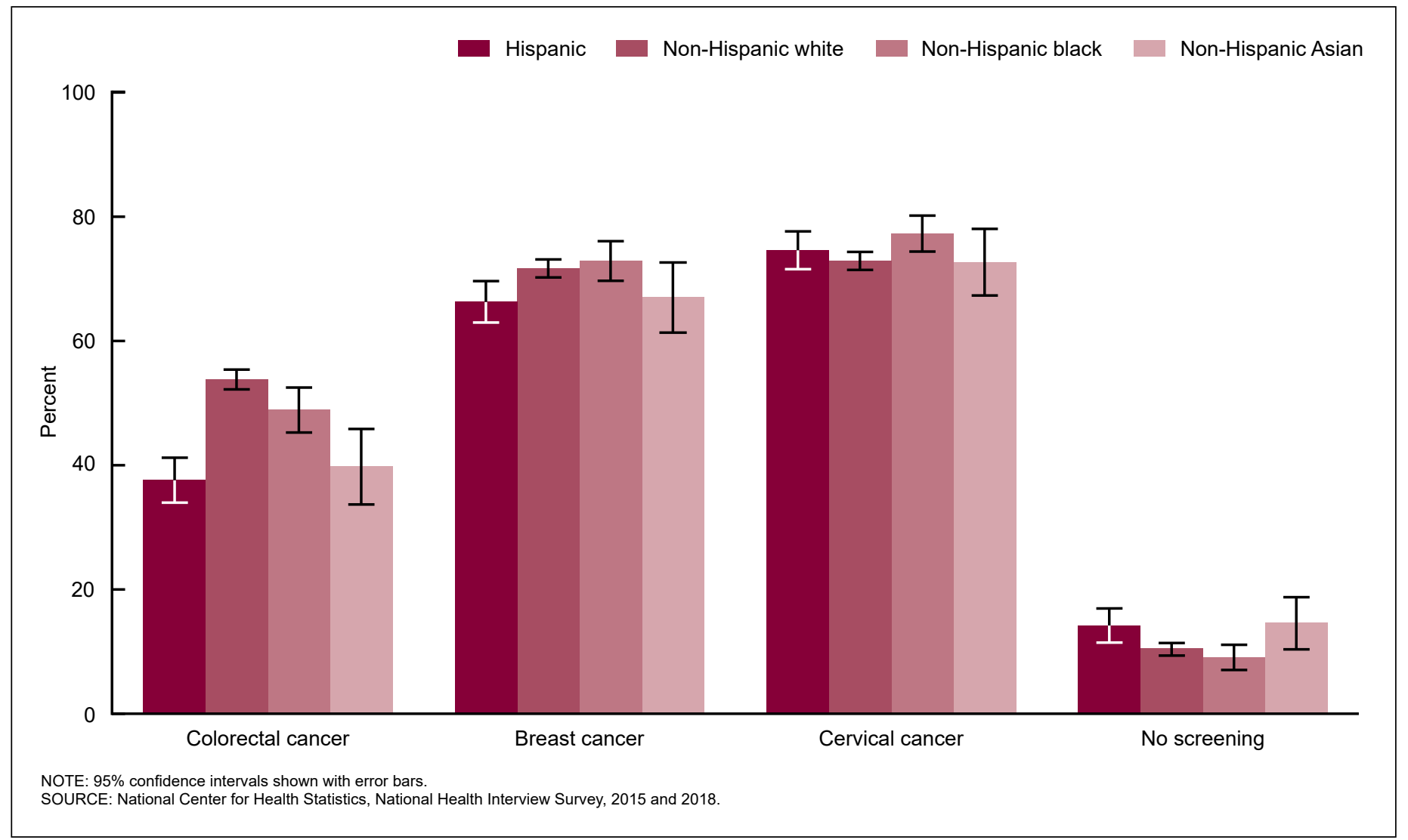

Figure 3. Age-adjusted percentage of colorectal, breast, and cervical cancer screening among women aged 45-64 and 65 and over, by poverty level: United States, 2015 and 2018

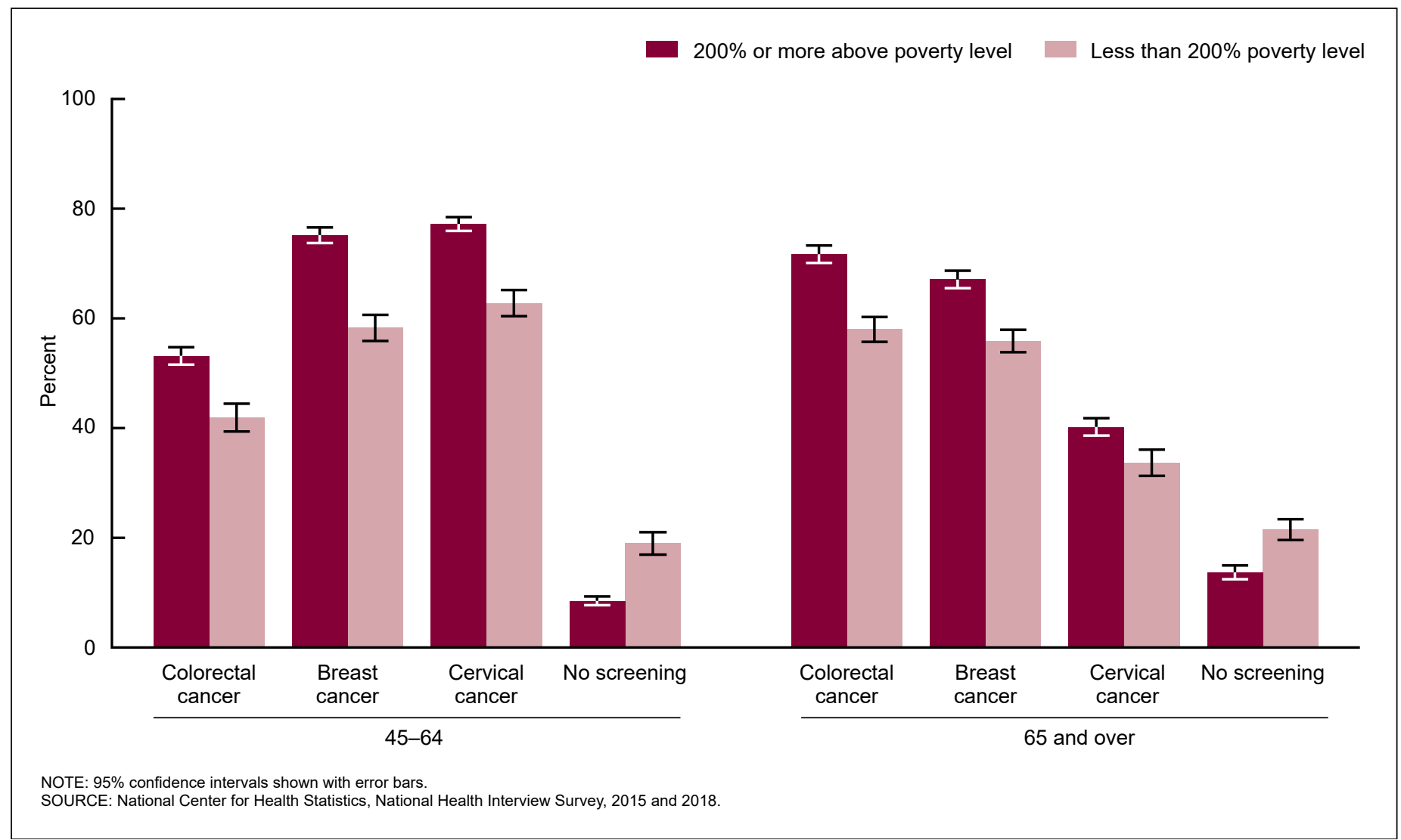


Figure 4. Percentage of colorectal, breast, and cervical cancer screening among women aged 45-64, by insurance status: United States, 2015 and 2018

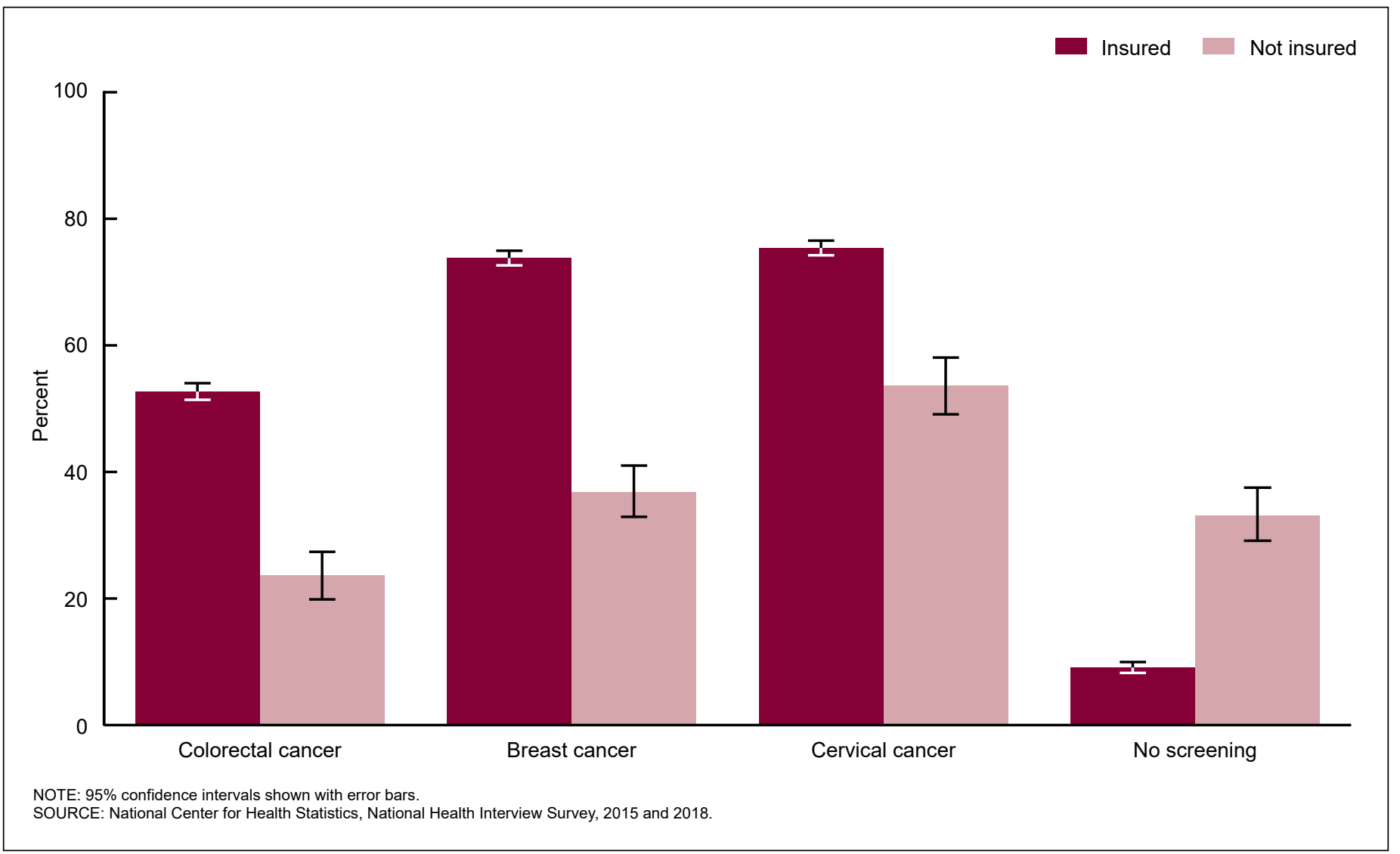

to report breast cancer screening $(64.7 \%$ and $64.1 \%$, respectively) compared with Hispanic women $(61.6 \%$ and $60.5 \%$, respectively) (Figure 5). Women with at least some college education were more likely to be screened for each of the three cancers. For each of the three cancers, the percentage screened was approximately 1.2 times higher among women with family income $200 \%$ or more above the poverty level $(71.7 \%$ for CRC; $67.1 \%$ for breast; and $40.2 \%$ for cervical) compared with women with lower income $(58.0 \%$ for CRC; $55.9 \%$ for breast; and 33.7\% for cervical) (Figure 3). Women who were married or living with a partner were also more likely to be screened for all three cancers compared with single, widowed, or divorced women. Women living outside of an MSA were more likely not to be screened for any of the three cancers $(21.3 \%$ compared with $15.4 \%$ among women living in an MSA), although the percentage of screening for each of the three cancers was similar by MSA status.

\section{Cancer screening by health status and health history characteristics}

\section{Women aged 45-64}

Women aged 45-64 who assessed their health as good or better were more likely to be screened for breast (72.2\%) and cervical (75.3\%) cancers but were less likely to be screened for CRC (49.4\%) compared with those who assessed their health as fair or poor (63.2\%, 64.0\%, and 54.2\%, respectively) (Table 2). Screening for CRC was about 1.4 to 1.5 times higher among women with one $(54.9 \%)$, two $(59.6 \%)$, or three or more conditions $(61.7 \%)$ compared with women with no conditions (40.7\%). Among women with three or more chronic conditions, the percentage screened was 1.2 times lower for cervical cancer $(63.0 \%)$ compared with those who did not report any chronic conditions $(74.7 \%)$. Women with a history of hysterectomy were 1.4 times more likely to be screened for CRC (64.1\%) and 1.1 times more likely to be screened for breast cancer (75.1\%) compared with women without these conditions $(46.1 \%$ and $69.4 \%$, respectively). Women who had had a hysterectomy were 1.3 times less likely to be screened for cervical cancer.

\section{Women aged 65 and over}

Among women aged 65 and over who assessed their health as good or better, the percentage screened was higher for each of the three cancers compared with those who assessed their health as fair or poor (Table 3). Percentages screened were 1.2 times higher for CRC (70.3\%) but were lower for cervical cancer $(33.0 \%)$ among women with three or more chronic conditions compared with those who did not report any chronic condition (59.5\% and $39.6 \%$, respectively). Women with a history of cancer were more likely to be screened for CRC and breast cancer. Women with a history of hysterectomy were more likely to be screened for $\mathrm{CRC}$ and breast cancer and less likely to be screened for cervical cancer 
Figure 5. Percentage of colorectal, breast, and cervical cancer screening among women aged 65 and over, by race and Hispanic origin: United States, 2015 and 2018

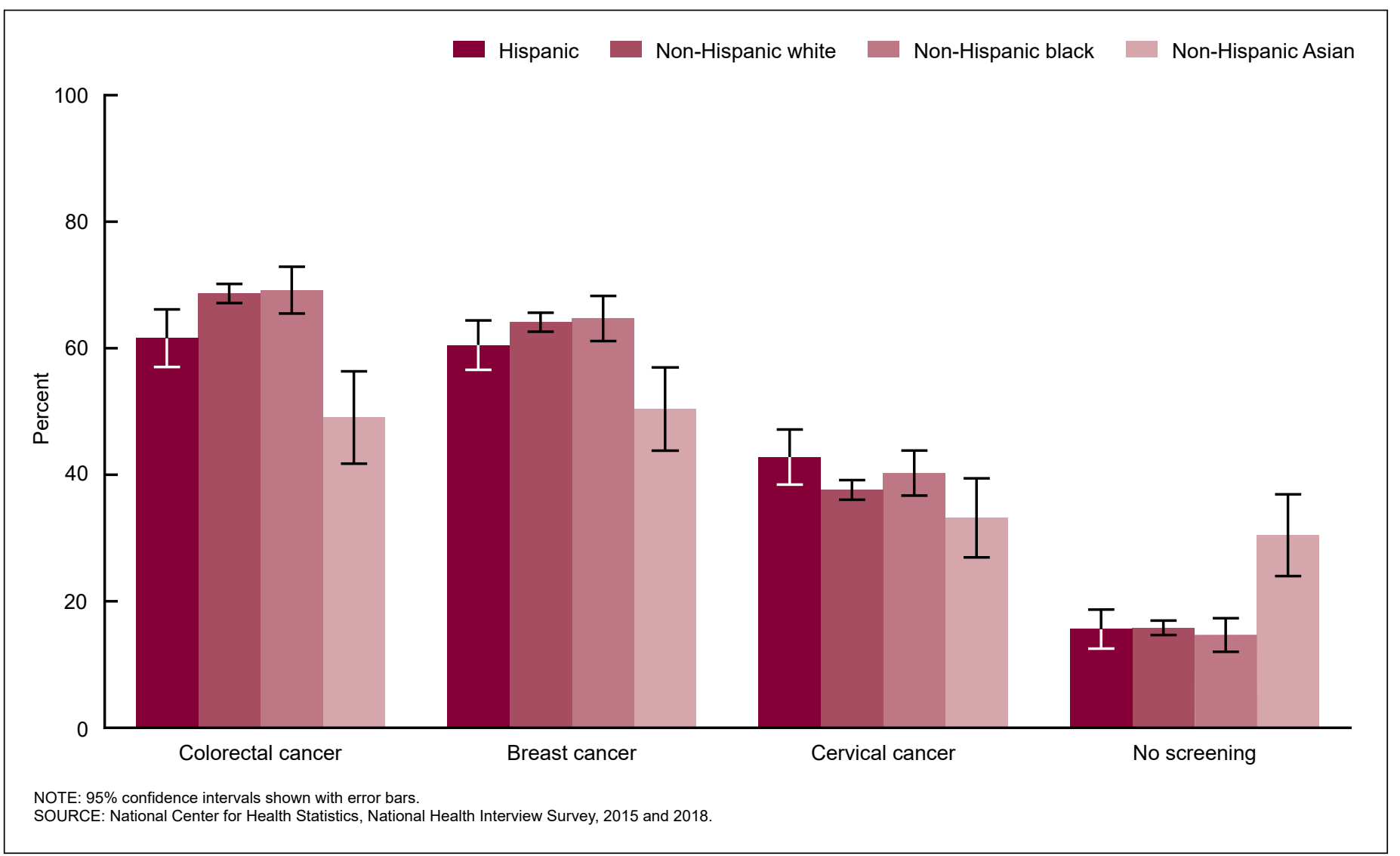

compared with those who did not report hysterectomy.

\section{Cancer screening by health behavior and health care utilization characteristics}

\section{Women aged 45-64}

Women aged 45-64 who were former or never smokers were more likely to report screening for each of the three types of cancer compared with current smokers, and less likely to receive no screening (Table 2). Among women who met the federal guidelines for physical activity, the percentages of those reporting being screened for each of the three cancers were approximately 1.1 times higher compared with those who did not meet the federal guidelines.

As shown in Figure 6, the percentages screened among women who received flu vaccination compared with percentages among those who did not were typically higher for each of the three cancers. Women who did not receive a flu shot in the past 12 months were about 3 times more likely not to have been screened for any of the three cancers (Table 2). Women who received health care 10 times or more in the past 12 months reported CRC screening at $62.1 \%$ compared with $47.8 \%$ among women who did not receive health care at this frequency. No significant differences were seen for the other cancer screenings.

\section{Women aged 65 and over}

Like women aged 45-64, among women aged 65 and over, former and never smokers were more likely to be screened for each of the three cancers compared with current smokers. Almost one-quarter of current smokers $(23.8 \%)$ did not receive screening for any of the three cancers compared with $15.6 \%$ of former and $15.8 \%$ of never smokers (Table 3). Among women who met the federal guidelines for physical activity, the percentage receiving screening for each type of the three cancers was higher compared with those who did not meet the federal guidelines.
Among women aged 65 and over, those who received a flu shot during the last 12 months were 1.4 times more likely to receive screening for CRC $(73.5 \%)$ and breast (69.6\%) cancer and 1.2 times more likely to receive screening for cervical cancer $(40.6 \%)$ compared with those who were not vaccinated $(53.1 \%$ for CRC; $49.2 \%$ for breast; and $32.7 \%$ for cervical). Those who were not vaccinated were 2.5 times less likely to be screened for any of the three cancers (Table 3 ). Women in this age group who received health care 10 or more times in the past 12 months were about as likely as those who did not receive care at the same frequency to receive screening for any of the three cancers.

\section{Discussion}

The American Cancer Society guidelines recommend routine $\mathrm{CRC}$ screening starting at age 45 and continuing through age 75 for men and women at average risk of developing CRC (40,41); annual breast cancer 
Figure 6. Age-adjusted percentage of colorectal, breast, and cervical cancer screening among women aged 45-64 and 65 and over, by receipt of a flu vaccine in the past 12 months: United States, 2015 and 2018

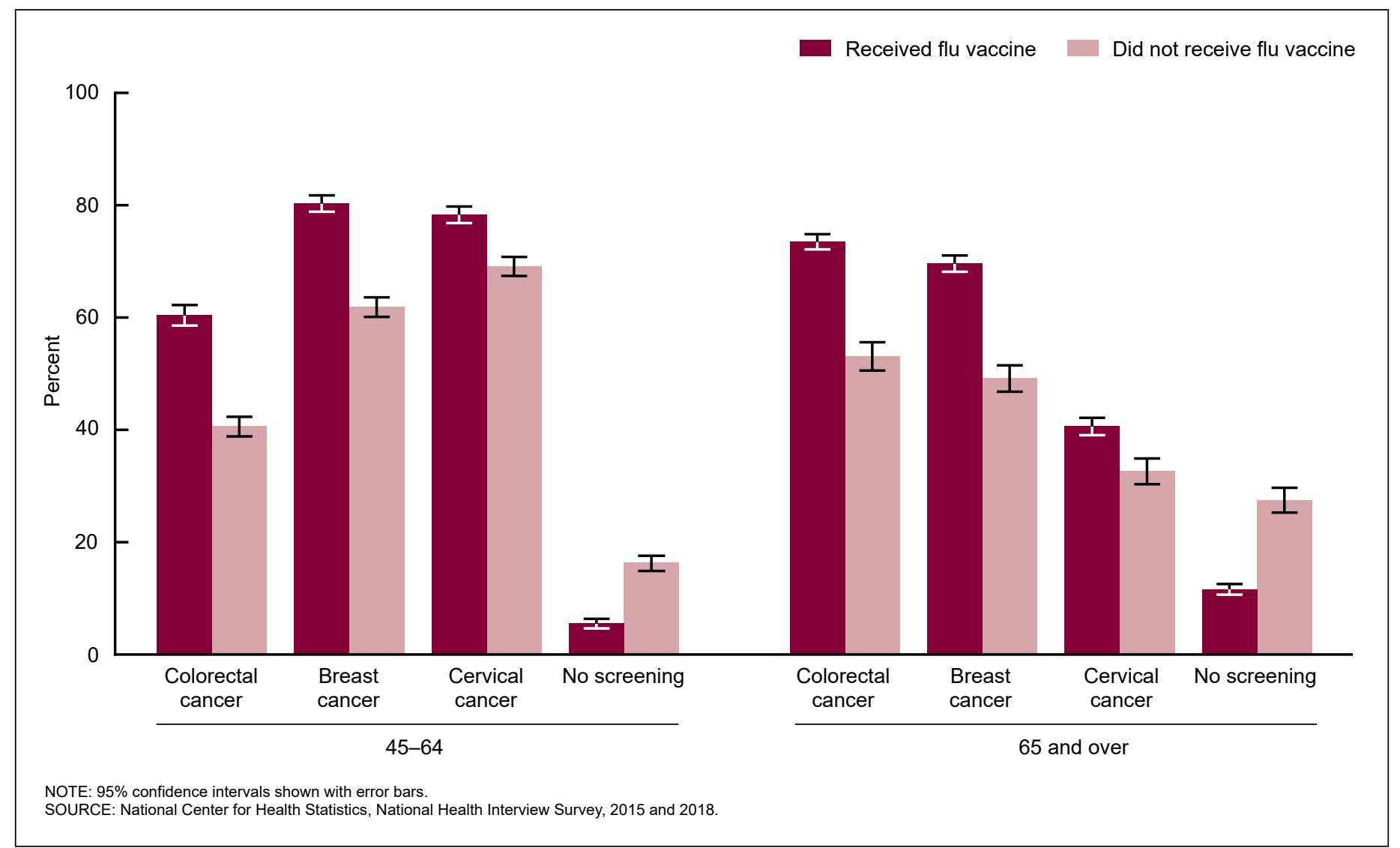

screening for women with an average risk of breast cancer starting at age 45 through 54, biennial mammograms after age 55, and advises mammography screening as long as their overall health is good and their life expectancy is 10 years or more $(42,43)$. American Cancer Society guidelines for cervical cancer are the same as current USPSTF guidelines $(16,41,44)$. Most of the publications cited in this report describe differences in cancer screening in accordance with the age groups consistent with USPSTF recommendations and American Cancer Society guidelines. This report focuses on describing differences in screening for colorectal, breast, and cervical cancer among women aged 45 and over. While it does not explain differences or disparities, it does provide descriptive information on the characteristics of women who receive CRC, breast, and cervical cancer screening, which may inform research aimed at reducing disparities in cancer screening among women aged 45 and over.

Patterns of screening vary by age depending on the type of cancer. The prevalence of screening for CRC and breast cancer generally decreased with age starting with age group 65-74. For cervical cancer screening, the decrease started with age group 55-64, while between the ages of 45 and 74 the prevalence of CRC screening increased and the prevalence of breast cancer screening did not change.

Non-Hispanic white and non-Hispanic black women were more likely to be screened for CRC among those aged 45 and over and for breast cancer among those aged 45-64 compared with Hispanic and non-Hispanic Asian women. No statistical difference was found in cancer screening among non-Hispanic white and non-Hispanic black women aged 65 and over. Lower screening percentages among Hispanic and non-Hispanic Asian women were consistent with findings in previous studies (45-48) that explained disparities by differences in access to care, disease awareness, cultural beliefs, and social difficulties inherent in acculturation.
In both age groups, women of lower socioeconomic status and those who were not married or living with a partner had a higher probability of receiving no screening for any of the three types of cancer. Women aged 45-64 with no insurance coverage were more than three times more likely not to receive cancer screening of any type compared with insured women. Generally, having one or more chronic conditions, a history of cancer or hysterectomy, or higher rates of receiving health care were associated with higher percentages of screening for CRC and breast cancer, but lower or similar percentages of screening for cervical cancer. Healthy behaviors such as not smoking, participating in physical activity, and receiving a flu shot were associated with higher percentages of screening.

Differences identified in this study are generally consistent with previous studies (24-29,49-51) on screening for colorectal, breast, and cervical cancer for women at average risk and within the age groups recommended for screening. The results of this study 
confirm that disparities persist in cancer screening among women aged 45 and over according to most of the selected characteristics regardless of recommended age of screening.

\section{Limitations}

The data on health status, health behavior, and cancer screening in this study are based on self reporting by respondents and, therefore, are subject to associated bias. Although no changes were seen in the 2015 and 2018 screening rates for CRC and breast cancer, screening rates for cervical cancer in 2015 were higher compared with rates in 2018 (76\% and $72 \%$ among women aged $45-64$ and $41 \%$ and $35 \%$ among women aged 65 and over, respectively). The study population does not include institutionalized women, such as nursing home residents. Another limitation of the study is that NHIS data do not distinguish between screening and diagnostic procedures, and some tests may have been performed as a part of treatment or post-treatment diagnostics among women with a history of cancer. Another limitation is that not all screening modalities for colorectal cancer and cervical cancer were included in the analysis.

\section{Conclusion}

Many programs promote cancer screening recommendations as a major component of early detection of disease in the hopes of increasing chances for successful treatment, specifically in underserved populations $(48,49,52-54)$. These results may inform efforts to reduce disparities in cancer screening among women aged 45 and over and help reduce disparities in cancer morbidity and mortality.

\section{References}

1. Heron M. Deaths: Leading causes for 2017. National Vital Statistics Reports; vol 68 no 6. Hyattsville, MD: National Center for Health Statistics. 2019.
2. National Center for Health Statistics, National Vital Statistics System mortality data. Available from: https://www.cdc.gov/nchs/nvss/ deaths.htm.

3. Plevritis SK, Munoz D, Kurian AW, Stout NK, Alagoz O, Near AM, et al. Association of screening and treatment with breast cancer mortality by molecular subtype in US women, 2000-2012. JAMA 319(2):154-64. 2018.

4. Nattinger AB, Mitchell JL. Breast cancer screening and prevention. Ann Intern Med 164(11):ITC81-ITC96. 2016.

5. Malmgren JA, Parikh J, Atwood MK, Kaplan HG. Improved prognosis of women aged 75 and older with mammography-detected breast cancer. Radiology 273(3):686-94. 2014.

6. Rosenblatt KA, Osterbur EF, Douglas JA. Case-control study of cervical cancer and gynecologic screening: A SEER-Medicare analysis. Gynecol Oncol 142(3):395-400. 2016.

7. Zoghbi ME, Cummings LC. New era of colorectal cancer screening. World J Gastrointest Endosc 8(5):252-8. 2016.

8. Thigpen SC, Geraci SA. Cancer screening 2016. Am J Med Sci 352(5):493-501. 2016.

9. Walter LC, Covinsky KE. Cancer screening in elderly patients: A framework for individualized decision making. JAMA 285(21):2750-6. 2001.

10. U.S. Preventive Services Task Force. Colorectal cancer: Screening. 2016. Available from: https://www. uspreventiveservicestaskforce.org/ uspstf/recommendation/ colorectal-cancer-screening.

11. US Preventive Services Task Force. Screening for colorectal cancer: US Preventive Services Task Force recommendation statement. JAMA 315(23): 2564-75. 2016.

12. U.S. Preventive Services Task Force. Colorectal cancer: Screening. An update for this topic is in progress. 2020.

13. U.S. Preventive Services Task Force. Breast cancer: Screening. 2016. Available from: https://www. uspreventiveservicestaskforce.org/ uspstf/recommendation/breast-cancerscreening.
14. Siu AL. U.S. Preventive Services Task Force. Screening for breast cancer: U.S. Preventive Services Task Force recommendation statement. Ann Intern Med 164(4):279-96. 2016.

15. U.S. Preventive Services Task Force. Cervical cancer: Screening. 2018. Available from: https:/www. uspreventiveservicestaskforce.org/ uspstf/recommendation/cervicalcancer-screening.

16. Sawaya GF, Kuppermann M. Identifying a "range of reasonable options" for cervical cancer screening. Obstet Gynecol 125(2):308-10. 2015.

17. Agency for Healthcare Research and Quality. The guide to clinical preventive services, 2014. Available from: https://www.ahrq.gov/sites/ default/files/publications/files/ cpsguide.pdf.

18. U.S. Centers for Medicare \& Medicaid Services. Medicare: Preventive \& screening services. Available from: https://www. medicare.gov/coverage/preventivescreening-services.

19. Health Resources \& Services Administration. Women's preventive services guidelines. Available from: https://www.hrsa.gov/womensguidelines/index.html.

20. American Cancer Society. Insurance coverage for colorectal cancer screening. Available from: https:/www.cancer.org/cancer/colonrectal-cancer/detection-diagnosisstaging/screening-coverage-laws.html.

21. Gates A, Ranji U, Snyder L. Coverage of preventive services for adults in Medicaid. The Kaiser Commission on Medicaid and the Uninsured. Issue Brief. 2014. Available from: https://www.kff.org/report-section/ coverage-of-preventive-services-foradults-in-medicaid-survey-findings/.

22. National Conference of State Legislatures. Colorectal cancer screening: What are states doing? 2011. Available from: http://www. ncsl.org/research/health/colorectalcancer-screening-laws-by-state.aspx.

23. National Center for Health Statistics. About the National Health Interview Survey. Available from: https://www. cdc.gov/nchs/nhis/about_nhis.htm.

24. Healthy People 2030. Increase the proportion of adults who get 
screened for colorectal cancer-C-07.

Available from: https://health.gov/

healthypeople/objectives-and-data/

browse-objectives/cancer/increase-

proportion-adults-who-get-screened-

colorectal-cancer-c-07.

25 . Healthy People 2030. Increase

the proportion of females who get

screened for breast cancer-C-05.

Available from: https://health.gov/

healthypeople/objectives-and-data/

browse-objectives/cancer/increase-

proportion-females-who-get-screened-

breast-cancer-c- 05 .

26. Healthy People 2030. Increase

the proportion of females who get screened for cervical cancer-C-09. Available from: https://health.gov/ healthypeople/objectives-and-data/ browse-objectives/cancer/increaseproportion-females-who-get-screenedcervical-cancer-c-09.

27. Burnett-Hartman AN, Mehta SJ, Zheng Y, Ghai NR, McLerran DF, Chubak J, et al. Racial/ethnic disparities in colorectal cancer screening across healthcare systems. Am J Prev Med 51(4):e107-15. 2016.

28. May FP, Yang L, Corona E, Glenn BA, Bastani R. Disparities in colorectal cancer screening in the United States before and after implementation of the Affordable Care Act. Clin Gastroenterol Hepatol 18(8):1796-1804.e2. 2019.

29. Tran L, Tran P. US urban-rural disparities in breast cancer-screening practices at the national, regional, and state level, 2012-2016. Cancer Causes Control 30(10):1045-55. 2019.

30. Sabatino SA, Thompson TD, White MC, Shapiro JA, de Moor J, Doria-Rose VP, et al. Cancer screening test receipt-United States, 2018. MMWR Morb Mortal Wkly Rep 70(2):29-35. 2021.

31. Henley SJ, Thomas CC, Lewis DR, Ward EM, Islami F, Wu M, et al. Annual report to the nation on the status of cancer, part II: Progress toward Healthy People 2020 objectives for 4 common cancers. Cancer 126(10):2250-66. 2020.

32. Shih YCT, Zhao L, Elting LS. Does Medicare coverage of colonoscopy reduce racial/ethnic disparities in cancer screening among the elderly? Health Aff (Millwood) 25(4):1153-62. 2006.

33. Hamman MK, Kapinos KA. Mandated coverage of preventive care and reduction in disparities: Evidence from colorectal cancer screening. Am J Public Health 105 Suppl 3(Suppl 3): S508-16. 2015.

34. Schenker N, Raghunathan TE, Chiu PL, Makuc DM, Zhang G, Cohen AJ. Multiple imputation of missing income data in the National Health Interview Survey. J Am Stat Assoc 101(475):924-33. 2006.

35. U.S. Department of Health \& Human Services. HHS poverty guidelines for 2021. Available from: https://aspe. hhs.gov/poverty-guidelines.

36. U.S. Office of Management and Budget. 2010 standards for delineating metropolitan and micropolitan statistical areas. Fed Regist 75(123):37245-52. 2010. Available from: https://www.govinfo. gov/content/pkg/FR-2010-06-28/ pdf/2010-15605.pdf.

37. U.S. Department of Health \& Human Services. Physical activity guidelines for Americans. 2008. Available from: https://health.gov/sites/default/ files/2019-09/paguide.pdf.

38. RTI International. SUDAAN (Release 11.0.0) [computer software]. 2012.

39. Parker JD, Talih M, Malec DJ, Beresovsky V, Carroll M, Gonzalez JF Jr, et al. National Center for Health Statistics data presentation standards for proportions. National Center for Health Statistics. Vital Health Stat 2(175). 2017.

40. American Cancer Society. American Cancer Society guideline for colorectal cancer screening. 2018. Available from: https://www.cancer. org/cancer/colon-rectal-cancer/ detection-diagnosis-staging/acsrecommendations.html.

41. Smith RA, Andrews KS, Brooks D, Fedewa SA, Manassaram-Baptiste D, Saslow D, et al. Cancer screening in the United States, 2017: A review of current American Cancer Society guidelines and current issues in cancer screening. CA Cancer J Clin 67(2):100-21. 2017.

42. American Cancer Society. American Cancer Society recommendations for the early detection of breast cancer. 2017. Available from: https://www.cancer.org/cancer/ breast-cancer/screening-tests-andearly-detection/american-cancersociety-recommendations-for-theearly-detection-of-breast-cancer.html.

43. Oeffinger KC, Fontham ETH, Etzioni R, Herzig A, Michaelson JS, Shih YCT, et al. Breast cancer screening for women at average risk: 2015 guideline update from the American Cancer Society. JAMA 314(15):1599-614. 2015.

44. Saslow D, Solomon D, Lawson HW, Killackey M, Kulasingam SL, Cain J, et al. American Cancer Society, American Society for Colposcopy and Cervical Pathology, and American Society for Clinical Pathology screening guidelines for the prevention and early detection of cervical cancer. Am J Clin Pathol 137(4):516-42. 2012.

45. Castañeda SF, Gallo LC, Nodora J, Talavera GA, Penedo FJ, Evenson $\mathrm{KR}$, et al. Colorectal cancer screening among Hispanics/Latinos in the HCHS/SOL sociocultural ancillary study. Prev Med Rep 15:100947. 2019.

46. Watts L, Joseph N, Velazquez A, Gonzalez M, Munro E, Muzikansky A, et al. Understanding barriers to cervical cancer screening among Hispanic women. Am J Obstet Gynecol 201(2):199.e1-8. 2009.

47. Shoemaker ML, White MC. Breast and cervical cancer screening among Asian subgroups in the USA: Estimates from the National Health Interview Survey, 2008, 2010, and 2013. Cancer Causes Control 27(6):825-9. 2016.

48. Fang CY, Ma GX, Tan Y. Overcoming barriers to cervical cancer screening among Asian American women. N Am J Med Sci (Boston) 4(2):77-83. 2011.

49. O’Connor SN, Tao J, Su LJ. Comparison of compliance with cervical cancer screening among women aged 18 and above in Arkansas and the United States. J Health Dispar Res Pract 11(4): 149-61. 2018.

50. Yu L, Sabatino SA, White MC. Rural-urban and racial/ethnic disparities in invasive cervical cancer 
incidence in the United States, 2010-2014. Prev Chronic Dis 16:E70. 2019.

51. Hall IJ, Tangka FKL, Sabatino SA, Thompson TD, Graubard BI, Breen N. Patterns and trends in cancer screening in the United States. Prev Chronic Dis 15:E97. 2018.

52. Joseph DA, King JB, Dowling NF, Thomas CC, Richardson LC. Vital signs: Colorectal cancer screening test use-United States, 2018.

MMWR Morb Mortal Wkly Rep 69(10):253-9. 2020.

53. Centers for Disease Control and Prevention. National breast and cervical cancer early detection program (NBCCEDP). Available from: https://www.cdc.gov/cancer/ nbccedp.

54. Centers for Disease Control and Prevention. Colorectal cancer control program (CRCCP). Available from: https://www.cdc.gov/cancer/crccp/. 
Table 1. Number and percentage of women surveyed, by population characteristics:

United States, 2015 and 2018

\begin{tabular}{|c|c|c|c|c|}
\hline Characteristic & $\begin{array}{l}\text { Ages } \\
45-64\end{array}$ & $\begin{array}{l}\text { Ages } 65 \\
\text { and over }\end{array}$ & $\begin{array}{l}\text { Ages } \\
45-64\end{array}$ & $\begin{array}{l}\text { Ages } 65 \\
\text { and over }\end{array}$ \\
\hline & \multicolumn{2}{|c|}{$\begin{array}{l}\text { Number (standard error) } \\
\text { (millions) }\end{array}$} & \multicolumn{2}{|c|}{ Percent (standard error) ${ }^{1}$} \\
\hline Noninstitutionalized women . . . . . . . . . & $42.9(0.6)$ & $27.0(0.4)$ & 100.0 & 100.0 \\
\hline \multicolumn{5}{|l|}{ Age } \\
\hline $45-54 \ldots \ldots \ldots \ldots \ldots \ldots \ldots \ldots \ldots \ldots \ldots \ldots$ & $21.6(0.4)$ & $\ldots$ & $50.3(0.6)$ & $\ldots$ \\
\hline $55-64 \ldots \ldots \ldots \ldots \ldots \ldots \ldots$ & $21.3(0.4)$ & $\ldots$ & $49.8(0.6)$ & $\ldots$ \\
\hline $65-74 \ldots \ldots \ldots \ldots \ldots \ldots \ldots \ldots$ & $\ldots$ & $15.4(0.3)$ & $\ldots$ & $57.1(0.7)$ \\
\hline $75-84 \ldots \ldots \ldots \ldots \ldots \ldots \ldots \ldots$ & $\ldots$ & $8.1(0.2)$ & $\ldots$ & $30.0(0.6)$ \\
\hline 85 and over. . . . . . . . . . . . & $\ldots$ & $3.5(0.1)$ & $\ldots$ & $13.0(0.5)$ \\
\hline \multicolumn{5}{|l|}{ Race and Hispanic origin } \\
\hline Hispanic . . . . . . . . . . . . . . & $5.7(0.2)$ & $2.3(0.1)$ & $13.3(0.5)$ & $8.5(0.4)$ \\
\hline Non-Hispanic white. . . . . . . . . . . & $28.6(0.5)$ & $20.5(0.4)$ & $66.7(0.7)$ & $75.8(0.7)$ \\
\hline Non-Hispanic black. . . . . . . . . . . . . . . & $5.3(0.2)$ & $2.5(0.1)$ & $12.4(0.5)$ & $9.4(0.4)$ \\
\hline Non-Hispanic Asian . . . . . . . . . . . & $2.4(0.2)$ & $1.2(0.1)$ & $5.7(0.3)$ & $4.6(0.4)$ \\
\hline \multicolumn{5}{|l|}{ Education } \\
\hline High school or less . . . . . . . . . . & $14.6(0.3)$ & $12.7(0.3)$ & $34.1(0.6)$ & $47.0(0.7)$ \\
\hline Some college or more $\ldots \ldots \ldots \ldots \ldots$ & $28.1(0.5)$ & $14.1(0.3)$ & $65.4(0.6)$ & $52.1(0.7)$ \\
\hline \multicolumn{5}{|l|}{ Poverty } \\
\hline Less than $200 \%$ poverty level. . . . . . . . . & $11.0(0.3)$ & $9.2(0.2)$ & $25.6(0.6)$ & $34.1(0.7)$ \\
\hline $200 \%$ or more above poverty level . . . . . . & $32.0(0.5)$ & $17.8(0.3)$ & $74.5(0.6)$ & $65.9(0.7)$ \\
\hline \multicolumn{5}{|l|}{ Marital status } \\
\hline Married or living with partner . . . . . . . & $28.7(0.5)$ & $12.9(0.3)$ & $67.0(0.6)$ & $47.9(0.7)$ \\
\hline Single, widowed, or other . . . . . . . . & $14.2(0.3)$ & $14.0(0.3)$ & $33.0(0.6)$ & $51.9(0.7)$ \\
\hline \multicolumn{5}{|l|}{ Insurance coverage } \\
\hline Yes ... & $39.1(0.6)$ & $26.9(0.4)$ & $91.2(0.4)$ & $99.3(0.1)$ \\
\hline$\ldots \ldots \ldots \ldots \ldots \ldots \ldots$ & $3.6(0.2)$ & $0.2(0.0)$ & $8.3(0.4)$ & $0.6(0.1)$ \\
\hline \multicolumn{5}{|l|}{ Geographic location } \\
\hline MSA . . . . . & $36.0(0.6)$ & $22.4(0.4)$ & $85.4(0.5)$ & $82.9(0.7)$ \\
\hline Non-MSA . . . . . . . . . . . . . & $6.3(0.2)$ & $4.6(0.2)$ & $14.6(0.5)$ & $17.1(0.7)$ \\
\hline \multicolumn{5}{|l|}{ Self-perceived health status } \\
\hline Excellent, very good, or good . . . . . . . & $35.9(0.6)$ & $21.2(0.4)$ & $83.6(0.5)$ & $78.4(0.6)$ \\
\hline 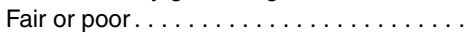 & $7.0(0.2)$ & $5.8(0.2)$ & $16.4(0.4)$ & $21.5(0.6)$ \\
\hline \multicolumn{5}{|l|}{ Number of chronic conditions ${ }^{2}$} \\
\hline None. . . . . . & $18.8(0.4)$ & $5.3(0.2)$ & $43.9(0.6)$ & $19.8(0.6)$ \\
\hline 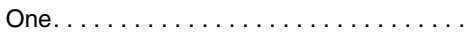 & $13.3(0.3)$ & $8.4(0.2)$ & $30.9(0.6)$ & $31.1(0.6)$ \\
\hline Two . . . . . . . . . . . . . . & $6.3(0.2)$ & $7.0(0.2)$ & $14.7(0.5)$ & $25.8(0.6)$ \\
\hline Three or more. . . . . . . . . . . & $4.5(0.2)$ & $6.3(0.2)$ & $10.5(0.4)$ & $23.3(0.6)$ \\
\hline \multicolumn{5}{|l|}{ Cancer (ever) } \\
\hline Yes $\ldots \ldots \ldots \ldots \ldots \ldots \ldots \ldots$ & $4.7(0.2)$ & $6.5(0.2)$ & $11.0(0.4)$ & $24.1(0.6)$ \\
\hline 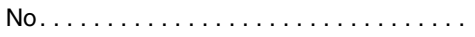 & $38.2(0.6)$ & $20.5(0.3)$ & $88.9(0.4)$ & $75.7(0.6)$ \\
\hline \multicolumn{5}{|l|}{ Hysterectomy } \\
\hline$\ldots \ldots \ldots \ldots \ldots \ldots \ldots$ & $9.3(0.3)$ & $10.3(0.2)$ & $21.8(0.5)$ & $38.0(0.7)$ \\
\hline No $\ldots \ldots \ldots \ldots \ldots \ldots \ldots \ldots \ldots \ldots \ldots$ & $31.0(0.5)$ & $15.4(0.3)$ & $72.3(0.6)$ & $56.9(0.7)$ \\
\hline \multicolumn{5}{|l|}{ Smoking status } \\
\hline Current $\ldots \ldots \ldots \ldots \ldots \ldots \ldots$ & $6.5(0.2)$ & $2.0(0.1)$ & $15.2(0.4)$ & $7.3(0.3)$ \\
\hline Former $\ldots \ldots \ldots \ldots \ldots \ldots \ldots$ & $9.2(0.3)$ & $8.3(0.2)$ & $21.5(0.5)$ & $30.8(0.6)$ \\
\hline Never $\ldots \ldots \ldots \ldots \ldots \ldots \ldots \ldots$ & $27.0(0.5)$ & $16.6(0.3)$ & $63.0(0.6)$ & $61.6(0.7)$ \\
\hline
\end{tabular}


Table 1. Number and percentage of women, by population characteristics: United States, 2015 and 2018-Con.

\begin{tabular}{|c|c|c|c|c|}
\hline Characteristic & $\begin{array}{c}\text { Ages } \\
45-64\end{array}$ & $\begin{array}{l}\text { Ages } 65 \\
\text { and over }\end{array}$ & $\begin{array}{l}\text { Ages } \\
45-64\end{array}$ & $\begin{array}{l}\text { Ages } 65 \\
\text { and over }\end{array}$ \\
\hline & \multicolumn{2}{|c|}{$\begin{array}{l}\text { Number (standard error) } \\
\text { (millions) }{ }^{1}\end{array}$} & \multicolumn{2}{|c|}{ Percent (standard error) ${ }^{1}$} \\
\hline \multicolumn{5}{|l|}{ Physical activity } \\
\hline Any ...... & $20.9(0.4)$ & $10.3(0.2)$ & $48.7(0.7)$ & $38.3(0.7)$ \\
\hline$\ldots \ldots \ldots \ldots \ldots \ldots$ & $21.1(0.4)$ & $16.1(0.3)$ & $49.2(0.7)$ & $60.0(0.7)$ \\
\hline \multicolumn{5}{|l|}{ Flu vaccination } \\
\hline Yes ..... & $20.1(0.4)$ & $18.4(0.3)$ & $47.0(0.6)$ & $68.0(0.6)$ \\
\hline 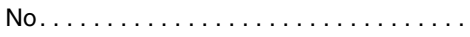 & $22.0(0.4)$ & $8.2(0.2)$ & $51.2(0.7)$ & $31.0(0.6)$ \\
\hline \multicolumn{5}{|l|}{ Received health care at least 10 times } \\
\hline Yes ........ & $7.0(0.2)$ & $5.2(0.2)$ & $16.4(0.5)$ & $19.4(0.5)$ \\
\hline No $\ldots \ldots \ldots \ldots \ldots \ldots \ldots \ldots \ldots \ldots \ldots \ldots$ & $35.8(0.6)$ & $21.7(0.4)$ & $83.5(0.5)$ & $80.3(0.5)$ \\
\hline
\end{tabular}

Category not applicable.

${ }^{1}$ Estimates were calculated using National Health Interview Survey (NHIS) Sample Adult weights and adjusted for the complex design of NHIS.

${ }^{2}$ The number of selected chronic conditions was calculated based on positive responses to the question, "Have you ever been told by a doctor or other health professional that you had: 1) cancer or a malignancy of any kind;2) chronic obstructive pulmonary disease (COPD); 3) diabetes (other than during pregnancy); 4) heart condition (coronary heart disease, angina, heart attack, or any other kind of heart disease); 5) asthma; 6) stroke; 7) hypertension; or 8) weak or failing kidneys in the past 12 months (excluding kidney stones, bladder infections, and incontinence)?"

SOURCE: National Center for Health Statistics, National Health Interview Survey, 2015 and 2018. 


\begin{tabular}{|c|c|c|c|c|c|c|c|c|}
\hline \multirow[b]{2}{*}{ Characteristic } & \multicolumn{2}{|c|}{ Colorectal cancer } & \multicolumn{2}{|c|}{ Breast cancer } & \multicolumn{2}{|c|}{ Cervical cancer } & \multicolumn{2}{|c|}{ No screening } \\
\hline & $\begin{array}{c}\text { Percent } \\
\text { (standard error) }\end{array}$ & $\begin{array}{l}\text { Prevalence ratio } \\
\text { (confidence interval) }\end{array}$ & $\begin{array}{c}\text { Percent } \\
{\text { (standard error })^{1}}^{\text {s. }}\end{array}$ & $\begin{array}{l}\text { Prevalence ratio } \\
\text { (confidence interval) }\end{array}$ & $\begin{array}{c}\text { Percent } \\
\text { (standard error) }^{1}\end{array}$ & $\begin{array}{l}\text { Prevalence ratio } \\
\text { (confidence interval) }\end{array}$ & $\begin{array}{c}\text { Percent } \\
\text { (standard error) }\end{array}$ & $\begin{array}{l}\text { Prevalence ratio } \\
\text { (confidence interval) }\end{array}$ \\
\hline All $\ldots \ldots \ldots \ldots \ldots \ldots \ldots \ldots \ldots \ldots \ldots \ldots \ldots \ldots \ldots \ldots$ & $50.1(0.7)$ & $\cdots$ & $70.7(0.6)$ & $\ldots$ & $73.5(0.6)$ & $\cdots$ & $11.1(0.4)$ & $\ldots$ \\
\hline \multicolumn{9}{|l|}{ Age } \\
\hline $45-54 \ldots \ldots \ldots \ldots \ldots \ldots \ldots \ldots \ldots \ldots$ & $34.0(0.9)$ & $1.00(\ldots)$ & $69.4(0.9)$ & $1.00(\ldots)$ & $78.3(0.8)$ & $1.00(\ldots)$ & $11.9(0.6)$ & $1.00(\ldots)$ \\
\hline 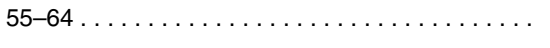 & $66.4(0.9)$ & $1.95(1.84-2.07)$ & $72.1(0.8)$ & $1.04(1.01-1.07)$ & $68.7(0.8)$ & $0.88(0.85-0.90)$ & $10.4(0.5)$ & $0.87(0.76-1.01)$ \\
\hline \multicolumn{9}{|l|}{ Race and Hispanic origin } \\
\hline Hispanic $\ldots \ldots \ldots \ldots \ldots \ldots \ldots$ & $37.6(1.8)$ & $1.00(\ldots)$ & $66.3(1.7)$ & $1.00(\ldots)$ & $74.6(1.6)$ & $1.00(\ldots)$ & $14.2(1.3)$ & $1.00(\ldots)$ \\
\hline Non-Hispanic white. . & $53.8(0.8)$ & $1.43(1.30-1.58)$ & $71.7(0.7)$ & $1.08(1.03-1.14)$ & $72.9(0.7)$ & $0.98(0.93-1.02)$ & $10.5(0.5)$ & $0.74(0.60-0.91)$ \\
\hline Non-Hispanic black. $\ldots \ldots \ldots \ldots \ldots \ldots \ldots$ & $48.9(1.8)$ & $1.30(1.16-1.46)$ & $72.9(1.6)$ & $1.10(1.03-1.17)$ & $77.3(1.5)$ & $1.04(0.98-1.10)$ & $9.1(1.0)$ & $0.64(0.49-0.85)$ \\
\hline Non-Hispanic Asian $\ldots \ldots \ldots \ldots \ldots \ldots \ldots$ & $39.8(3.0)$ & $1.06(0.88-1.27)$ & $67.0(2.8)$ & $1.01(0.92-1.11)$ & $72.7(3.8)$ & $0.97(0.90-1.06)$ & $14.6(2.1)$ & $1.03(0.73-1.44)$ \\
\hline \multicolumn{9}{|l|}{ Education } \\
\hline High school or less. . . . . . . . . . & $43.4(1.1)$ & $1.00(\ldots)$ & $63.8(1.1)$ & $1.00(\ldots)$ & $66.9(1.0)$ & $1.00(\ldots)$ & $15.4(0.8)$ & $1.00(\ldots)$ \\
\hline Some college or more $\ldots \ldots \ldots \ldots$ & $53.7(0.8)$ & $1.24(1.17-1.31)$ & $74.4(0.7)$ & $1.17(1.12-1.21)$ & $77.1(0.7)$ & $1.15(1.11-1.19)$ & $8.8(0.5)$ & $0.57(0.49-0.66)$ \\
\hline \multicolumn{9}{|l|}{ Poverty } \\
\hline $200 \%$ or more above poverty level $\ldots \ldots \ldots \ldots$ & $52.9(0.8)$ & $1.26(1.18-1.34)$ & $74.9(0.7)$ & $1.28(1.23-1.34)$ & $77.2(0.6)$ & $1.23(1.18-1.28)$ & $8.5(0.4)$ & $0.44(0.38-0.51)$ \\
\hline \multicolumn{9}{|l|}{ Marital status } \\
\hline Married or living with partner $\ldots \ldots \ldots \ldots \ldots$ & $51.1(0.8)$ & $1.07(1.01-1.12)$ & $72.7(0.7)$ & $1.09(1.05-1.13)$ & $75.5(0.7)$ & $1.09(1.05-1.12)$ & $10.0(0.5)$ & $0.74(0.64-0.84)$ \\
\hline Single, widowed, or other $\ldots \ldots \ldots \ldots \ldots \ldots$ & $48.0(1.0)$ & $1.00(\ldots)$ & $66.6(1.0)$ & $1.00(\ldots)$ & $69.5(0.9)$ & $1.00(\ldots)$ & $13.5(0.7)$ & $1.00(\ldots)$ \\
\hline \multicolumn{9}{|l|}{ Insurance coverage } \\
\hline Yes & $52.7(0.7)$ & $2.23(1.90-2.61)$ & $73.8(0.6)$ & $2.01(1.80-2.24)$ & $75.4(0.7)$ & $1.41(1.30-1.53)$ & $9.1(0.4)$ & $0.27(0.24-0.32)$ \\
\hline No............................. & $23.7(1.9)$ & $1.00(\ldots)$ & $36.8(2.1)$ & $1.00(\ldots)$ & $53.6(2.2)$ & $1.00(\ldots)$ & $33.1(1.8)$ & $1.00(\ldots)$ \\
\hline \multicolumn{9}{|l|}{ Geographic location } \\
\hline $\operatorname{MSA} \ldots \ldots \ldots \ldots \ldots \ldots \ldots \ldots \ldots \ldots \ldots \ldots \ldots \ldots \ldots$ & $50.5(0.7)$ & $1.04(0.97-1.12)$ & $71.7(0.6)$ & $1.10(1.05-1.16)$ & $75.0(0.6)$ & $1.15(1.10-1.21)$ & $10.2(0.4)$ & $0.61(0.51-0.73)$ \\
\hline Non-MSA $\ldots \ldots \ldots \ldots \ldots \ldots \ldots \ldots \ldots \ldots$ & $48.4(1.5)$ & $1.00(\ldots)$ & $65.1(1.5)$ & $1.00(\ldots)$ & $65.1(1.5)$ & $1.00(\ldots)$ & $16.7(1.3)$ & $1.00(\ldots)$ \\
\hline \multicolumn{9}{|l|}{ Self-perceived health status } \\
\hline Excellent, very good, or good............. & $49.4(0.7)$ & $0.91(0.86-0.97)$ & $72.2(0.6)$ & $1.14(1.08-1.20)$ & $75.3(0.6)$ & $1.18(1.12-1.24)$ & $10.8(0.5)$ & $0.82(0.69-0.97)$ \\
\hline 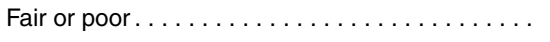 & $54.2(1.6)$ & $1.00(\ldots)$ & $63.2(1.5)$ & $1.00(\ldots)$ & $64.0(1.5)$ & $1.00(\ldots)$ & $13.1(1.0)$ & $1.00(\ldots)$ \\
\hline \multicolumn{9}{|l|}{ Number of chronic conditions ${ }^{2}$} \\
\hline None............................ & $40.7(1.0)$ & $1.00(\ldots)$ & $67.8(0.9)$ & $1.00(\ldots)$ & $74.7(0.9)$ & $1.00(\ldots)$ & $14.0(0.7)$ & $1.00(\ldots)$ \\
\hline 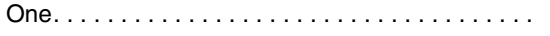 & $54.9(1.2)$ & $1.35(1.27-1.44)$ & $73.9(1.0)$ & $1.09(1.05-1.13)$ & $76.0(1.0)$ & $1.02(0.98-1.05)$ & $9.2(0.7)$ & $0.66(0.56-0.79)$ \\
\hline Two $\ldots \ldots \ldots \ldots \ldots \ldots \ldots \ldots \ldots$ & $59.6(1.7)$ & $1.47(1.36-1.58)$ & $74.2(1.5)$ & $1.09(1.04-1.15)$ & $72.4(1.4)$ & $0.97(0.93-1.01)$ & $7.4(0.9)$ & $0.53(0.41-0.68)$ \\
\hline 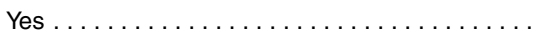 & $68.8(1.8)$ & $1.44(1.36-1.53)$ & $75.6(1.5)$ & $1.08(1.03-1.13)$ & $70.0(1.8)$ & $0.95(0.90-1.0)$ & $6.2(0.8)$ & $0.53(0.40-0.70)$ \\
\hline 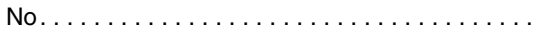 & $47.8(0.7)$ & $1.00(\ldots)$ & $70.1(0.6)$ & $1.00(\ldots)$ & $74.0(0.6)$ & $1.00(\ldots)$ & $11.7(0.5)$ & $1.00(\ldots)$ \\
\hline \multicolumn{9}{|l|}{ Hysterectomy } \\
\hline Yes $\ldots \ldots \ldots \ldots \ldots \ldots \ldots \ldots \ldots \ldots \ldots \ldots$ & $64.1(1.3)$ & $1.39(1.32-1.46)$ & $75.1(1.1)$ & $1.08(1.04-1.12)$ & $54.0(1.3)$ & $0.68(0.65-0.71)$ & $9.9(0.8)$ & $0.86(0.71-1.03)$ \\
\hline No............................. & $46.1(0.8)$ & $1.00(\ldots)$ & $69.4(0.7)$ & $1.00(\ldots)$ & $79.4(0.6)$ & $1.00(\ldots)$ & $11.5(0.5)$ & $1.00(\ldots)$ \\
\hline
\end{tabular}


Table 2. Cancer screening among women aged 45-64: United States, 2015 and 2018—Con.

\begin{tabular}{|c|c|c|c|c|c|c|c|c|}
\hline \multirow[b]{2}{*}{ Characteristic } & \multicolumn{2}{|c|}{ Colorectal cancer } & \multicolumn{2}{|c|}{ Breast cancer } & \multicolumn{2}{|c|}{ Cervical cancer } & \multicolumn{2}{|c|}{ No screening } \\
\hline & $\begin{array}{c}\text { Percent } \\
\text { (standard error) }^{1}\end{array}$ & $\begin{array}{c}\text { Prevalence ratio } \\
\text { (confidence interval) }\end{array}$ & $\begin{array}{c}\text { Percent } \\
\text { (standard error) }^{1}\end{array}$ & $\begin{array}{c}\text { Prevalence ratio } \\
\text { (confidence interval) }\end{array}$ & $\begin{array}{c}\text { Percent } \\
\text { (standard error) }^{1}\end{array}$ & $\begin{array}{c}\text { Prevalence ratio } \\
\text { (confidence interval) }\end{array}$ & $\begin{array}{c}\text { Percent } \\
{\text { (standard error })^{1}}^{1}\end{array}$ & $\begin{array}{c}\text { Prevalence ratio } \\
\text { (confidence interval) }\end{array}$ \\
\hline \multicolumn{9}{|l|}{ Smoking status } \\
\hline$\ldots \ldots \ldots \ldots$ & $39.2(1.5)$ & $1.00(\ldots)$ & $54.3(1.6)$ & $1.00(\ldots)$ & $60.1(1.6)$ & $1.00(\ldots)$ & $21.1(1.4)$ & $1.00(\ldots)$ \\
\hline$\ldots \ldots \ldots \ldots$ & $61.3(1.3)$ & $1.56(1.43-1.70)$ & $73.4(1.2)$ & $1.35(1.27-1.44)$ & $72.9(1.2)$ & $1.21(1.14-1.29)$ & $8.8(0.7)$ & $0.42(0.34-0.51)$ \\
\hline Never $\ldots \ldots \ldots \ldots \ldots \ldots$ & $48.9(0.8)$ & $1.25(1.15-1.35)$ & $73.7(0.7)$ & $1.36(1.28-1.44)$ & $77.0(0.7)$ & $1.28(1.21-1.35)$ & $9.5(0.5)$ & $0.45(0.38-0.53)$ \\
\hline \multicolumn{9}{|l|}{ Physical activity } \\
\hline Any $\ldots \ldots \ldots \ldots \ldots \ldots$ & $52.5(0.9)$ & $1.10(1.04-1.16)$ & $75.3(0.8)$ & $1.14(1.10-1.18)$ & $78.2(0.7)$ & $1.14(1.10-1.17)$ & $8.4(0.5)$ & $0.60(0.52-0.70)$ \\
\hline None.................. & $47.8(1.0)$ & $1.00(\ldots)$ & $66.3(0.9)$ & $1.00(\ldots)$ & $68.9(0.9)$ & $1.00(\ldots)$ & $13.9(0.7)$ & $1.00(\ldots)$ \\
\hline \multicolumn{9}{|l|}{ Flu vaccination } \\
\hline$\ldots \ldots \ldots \ldots$ & $60.4(0.9)$ & $1.49(1.41-1.56)$ & $80.3(0.7)$ & $1.30(1.26-1.34)$ & $78.3(0.7)$ & $1.13(1.10-1.17)$ & $5.5(0.4)$ & $0.34(0.29-0.40)$ \\
\hline No $\ldots \ldots \ldots \ldots \ldots \ldots$ & $40.6(0.9)$ & $1.00(\ldots)$ & $61.9(0.9)$ & $1.00(\ldots)$ & $69.1(0.8)$ & $1.00(\ldots)$ & $16.3(0.7)$ & $1.00(\ldots)$ \\
\hline \multicolumn{9}{|c|}{ Received health care at least 10 times } \\
\hline Yes $\ldots \ldots \ldots \ldots \ldots \ldots$. & $62.1(1.5)$ & $1.30(1.23-1.37)$ & $71.6(1.4)$ & $1.02(0.98-1.06)$ & $72.9(1.3)$ & $0.99(0.95-1.03)$ & $6.5(0.7)$ & $0.54(0.43-0.68)$ \\
\hline No................. & $47.8(0.7)$ & $1.00(\ldots)$ & $70.5(0.7)$ & $1.00(\ldots)$ & $73.7(0.6)$ & $1.00(\ldots)$ & $12.0(0.5)$ & $1.00(\ldots)$ \\
\hline \multirow{2}{*}{\multicolumn{9}{|c|}{$\begin{array}{l}\text { W. Category not applicable. } \\
\text { "Estimates were calculated using National Health Interview Survey (NHIS) Sample Adult weights and adjusted for the complex design of NHIS. } \\
\text { 2The number of selected chronic conditions was calculated based on positive responses to the question, "Have you ever been told by a doctor or other health professional that you had: 1) cancer or a malignancy of any kind; } 2 \text { ) chronic obstructive pulmonary } \\
\text { disease (COPD); ;) diabetes (other than during pregnancy); 4) heart condition (coronary heart disease, angina, heart attack, or any other kind of heart disease); 5) asthma; 6) stroke; 7) hypertension; or 8) weak or failing kidneys in the past } 12 \text { months (excluding } \\
\text { kidney stones, bladder infections, and incontinence)?" } \\
\text { NOTE: MSA is metropolitan statistical area. }\end{array}$}} \\
\hline & & & & & & & & \\
\hline \multicolumn{9}{|c|}{ SOURCE: National Center for Health Statistics, National Health Interview Survey, 2015 and 2018.} \\
\hline
\end{tabular}




\begin{tabular}{|c|c|c|c|c|c|c|c|c|}
\hline \multirow[b]{2}{*}{ Characteristic } & \multicolumn{2}{|c|}{ Colorectal cancer } & \multicolumn{2}{|c|}{ Breast cancer } & \multicolumn{2}{|c|}{ Cervical cancer } & \multicolumn{2}{|c|}{ None } \\
\hline & $\begin{array}{c}\text { Percent } \\
\text { (standard error) }^{1,2}\end{array}$ & $\begin{array}{c}\text { Prevalence ratio } \\
\text { (confidence interval) }\end{array}$ & $\begin{array}{c}\text { Percent } \\
\text { (standard error) }{ }^{1,2}\end{array}$ & $\begin{array}{l}\text { Prevalence ratio } \\
\text { (confidence interval) }\end{array}$ & $\begin{array}{c}\text { Percent } \\
\text { (standard error) }{ }^{1,2}\end{array}$ & $\begin{array}{c}\text { Prevalence ratio } \\
\text { (confidence interval) }\end{array}$ & $\begin{array}{c}\text { Percent } \\
\text { (standard error) }^{1,2}\end{array}$ & $\begin{array}{l}\text { Prevalence ratio } \\
\text { (confidence interval) }\end{array}$ \\
\hline 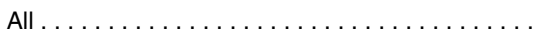 & $67.2(0.6)$ & $\ldots$ & $63.3(0.7)$ & $\ldots$ & $38.1(0.7)$ & $\ldots$ & $16.4(0.5)$ & $\cdots$ \\
\hline \multicolumn{9}{|l|}{ Age } \\
\hline 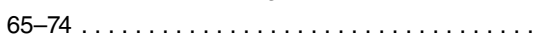 & $72.4(0.8)$ & $1.00(\ldots)$ & $73.7(0.8)$ & $1.00(\ldots)$ & $50.2(1.0)$ & $1.00(\ldots)$ & $10.3(0.6)$ & $1.00(\ldots)$ \\
\hline${ }^{75}-84, \ldots 2 \ldots$ & $66.5(1.1)$ & $0.92(0.88-0.96)$ & $59.0(1.2)$ & $0.80(0.76-0.84)$ & $28.9(1.1)$ & $0.58(0.53-0.63)$ & $17.5(0.9)$ & $1.70(1.47-1.97)$ \\
\hline \multicolumn{9}{|l|}{ Race and Hispanic origin } \\
\hline Hispanic . . . . . . . . . . . . . & $61.6(2.3)$ & $1.00(\ldots)$ & $60.5(2.0)$ & $1.00(\ldots)$ & $42.8(2.2)$ & $1.00(\ldots)$ & $15.6(1.5)$ & $1.00(\ldots)$ \\
\hline Non-Hispanic white $\ldots \ldots \ldots \ldots \ldots \ldots \ldots$ & $68.7(0.7)$ & $1.13(1.05-1.21)$ & $64.1(0.8)$ & $1.04(0.98-1.11)$ & $37.6(0.8)$ & $0.87(0.79-0.97)$ & $15.8(0.6)$ & $1.03(0.84-1.26)$ \\
\hline Non-Hispanic black. $\ldots \ldots \ldots \ldots \ldots \ldots \ldots$ & $69.2(1.8)$ & $1.13(1.04-1.23)$ & $64.7(1.8)$ & $1.06(0.98-1.15)$ & $40.3(1.8)$ & $0.95(0.84-1.07)$ & $14.7(1.3)$ & $0.93(0.72-1.20)$ \\
\hline Non-Hispanic Asian $\ldots \ldots \ldots \ldots \ldots \ldots \ldots$ & $49.1(3.6)$ & $0.82(0.71-0.96)$ & $50.4(3.3)$ & $0.86(0.75-0.98)$ & $33.2(3.1)$ & $0.77(0.63-0.95)$ & $30.5(3.2)$ & $1.95(1.48-2.56)$ \\
\hline \multicolumn{9}{|l|}{ Education } \\
\hline High school or less......... & $62.8(1.0)$ & $1.00(\ldots)$ & $59.2(1.0)$ & $1.00(\ldots)$ & $35.2(1.0)$ & $1.00(\ldots)$ & $19.1(0.8)$ & $1.00(\ldots)$ \\
\hline Some college or more $\ldots \ldots \ldots \ldots \ldots \ldots$ & $71.3(0.9)$ & $1.13(1.09-1.18)$ & $67.6(0.9)$ & $1.14(1.09-1.18)$ & $40.8(1.0)$ & $1.16(1.08-1.24)$ & $13.8(0.7)$ & $0.71(0.63-0.81)$ \\
\hline Less than $200 \%$ poverty level. . . . . . . . . . . . & $58.0(1.2)$ & $1.00(\ldots)$ & $55.9(1.1)$ & $1.00(\ldots)$ & $33.7(1.1)$ & $1.00(\ldots)$ & $21.5(1.0)$ & $1.00(\ldots)$ \\
\hline $200 \%$ or more above poverty level $\ldots \ldots \ldots \ldots$ & $71.7(0.8)$ & $1.23(1.18-1.28)$ & $67.1(0.8)$ & $1.19(1.14-1.24)$ & $40.2(0.9)$ & $1.18(1.10-1.28)$ & $13.7(0.6)$ & $0.65(0.58-0.73)$ \\
\hline \multicolumn{9}{|l|}{ Marital status } \\
\hline Married or living with partner $\ldots \ldots \ldots \ldots \ldots$ & $71.2(1.1)$ & $1.13(1.09-1.18)$ & $69.0(1.1)$ & $1.17(1.12-1.21)$ & $41.3(1.0)$ & $1.22(1.14-1.31)$ & $12.9(0.9)$ & $0.66(0.57-0.76)$ \\
\hline Single, widowed, or other $\ldots \ldots \ldots \ldots \ldots \ldots$ & $63.1(0.9)$ & $1.00(\ldots)$ & $58.6(0.8)$ & $1.00(\ldots)$ & $34.1(0.9)$ & $1.00(\ldots)$ & $19.2(0.7)$ & $1.00(\ldots)$ \\
\hline \multicolumn{9}{|l|}{ Geographic location } \\
\hline $\operatorname{MSA} \ldots \ldots \ldots \ldots \ldots \ldots$ & $68.4(0.7)$ & $1.11(1.06-1.17)$ & $64.4(0.7)$ & $1.11(1.05-1.17)$ & $38.7(0.7)$ & $1.09(0.99-1.20)$ & $15.4(0.6)$ & $0.71(0.62-0.82)$ \\
\hline Non-MSA ..... & $61.2(1.3)$ & $1.00(\ldots)$ & $58.0(1.5)$ & $1.00(\ldots)$ & $35.5(1.6)$ & $1.00(\ldots)$ & $21.3(1.2)$ & $1.00(\ldots)$ \\
\hline \multicolumn{9}{|l|}{ Self-perceived health status } \\
\hline Excellent, very good, or good......... & $68.6(0.7)$ & $1.11(1.05-1.17)$ & $65.7(0.7)$ & $1.20(1.13-1.27)$ & $38.9(0.7)$ & $1.12(1.02-1.22)$ & $15.6(0.6)$ & $0.82(0.72-094)$ \\
\hline Fair or poor $\ldots \ldots \ldots \ldots \ldots \ldots \ldots$ & $61.7(1.5)$ & $1.00(\ldots)$ & $54.7(1.4)$ & $1.00(\ldots)$ & $34.9(1.5)$ & $1.00(\ldots)$ & $19.2(1.2)$ & $1.00(\ldots)$ \\
\hline \multicolumn{9}{|l|}{ Number of chronic conditions ${ }^{4}$} \\
\hline None $\ldots \ldots \ldots \ldots \ldots \ldots \ldots \ldots \ldots \ldots \ldots$ & $59.5(1.7)$ & $1.00(\ldots)$ & $60.7(1.7)$ & $1.00(\ldots)$ & $39.6(1.5)$ & $1.00(\ldots)$ & $21.7(1.4)$ & $1.00(\ldots)$ \\
\hline 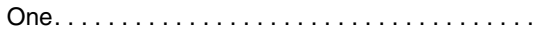 & $66.7(1.1)$ & $1.11(1.05-1.18)$ & $64.1(1.1)$ & $1.06(1.00-1.12)$ & $40.3(1.1)$ & $1.01(0.92-1.09)$ & $16.1(0.8)$ & $0.72(0.61-0.85)$ \\
\hline Two .............. & $70.0(1.2)$ & $1.16(1.09-1.23)$ & $63.4(1.3)$ & $1.04(0.97-1.10)$ & $37.6(1.3)$ & $0.93(0.84-1.02)$ & $14.8(0.9)$ & $0.67(0.55-0.80)$ \\
\hline Three or more............ & $70.3(1.3)$ & $1.17(1.10-1.25)$ & $64.0(1.3)$ & $1.05(0.99-1.12)$ & $33.0(1.3)$ & $0.81(0.73-0.90)$ & $14.6(1.0)$ & $0.67(0.55-0.81)$ \\
\hline \multicolumn{9}{|l|}{ Cancer (ever) } \\
\hline \multicolumn{9}{|l|}{ Hysterectomy } \\
\hline Yes & $73.5(0.9)$ & $1.17(1.13-1.21)$ & $67.4(1.0)$ & $1.11(1.07-1.15)$ & $29.9(1.0)$ & $0.68(0.63-0.74)$ & $13.6(0.7)$ & $0.74(0.65-0.84)$ \\
\hline 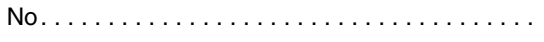 & $62.9(0.9)$ & $1.00(\ldots)$ & $60.5(0.9)$ & $1.00(\ldots)$ & $43.3(0.9)$ & $1.00(\ldots)$ & $18.4(0.7)$ & $1.00(\ldots)$ \\
\hline
\end{tabular}


Table 3. Age-adjusted cancer screening among women aged 65 and over: United States, 2015 and 2018—Con.

\begin{tabular}{|c|c|c|c|c|c|c|c|c|}
\hline \multirow[b]{2}{*}{ Characteristic } & \multicolumn{2}{|c|}{ Colorectal cancer } & \multicolumn{2}{|c|}{ Breast cancer } & \multicolumn{2}{|c|}{ Cervical cancer } & \multicolumn{2}{|c|}{ None } \\
\hline & $\begin{array}{c}\text { Percent } \\
\text { (standard error) }^{1,2}\end{array}$ & $\begin{array}{l}\text { Prevalence ratio } \\
\text { (confidence interval) }\end{array}$ & $\begin{array}{c}\text { Percent } \\
\text { (standard error) }{ }^{1,2}\end{array}$ & $\begin{array}{l}\text { Prevalence ratio } \\
\text { (confidence interval) }\end{array}$ & $\begin{array}{c}\text { Percent } \\
\text { (standard error) } \text { (1,2 }^{1}\end{array}$ & $\begin{array}{l}\text { Prevalence ratio } \\
\text { (confidence interval) }\end{array}$ & $\begin{array}{c}\text { Percent } \\
\text { (standard error) }{ }^{1,2}\end{array}$ & $\begin{array}{c}\text { Prevalence ratio } \\
\text { (confidence interval) }\end{array}$ \\
\hline \multicolumn{9}{|l|}{ Smoking status } \\
\hline Current $\ldots \ldots \ldots \ldots \ldots \ldots \ldots \ldots \ldots \ldots \ldots$ & $57.7(2.8)$ & $1.00(\ldots)$ & $47.8(2.7)$ & $1.00(\ldots)$ & $31.8(2.5)$ & $1.00(\ldots)$ & $23.8(2.5)$ & $1.00(\ldots)$ \\
\hline$\ldots \ldots \ldots, \ldots \omega_{n}$ & $70.6(1.1)$ & $1.24(1.14-1.35)$ & $63.4(1.1)$ & $1.32(1.20-1.45)$ & $37.9(1.2)$ & $1.23(1.07-1.42)$ & $15.6(0.9)$ & $0.54(0.43-0.68)$ \\
\hline$\ldots \ldots \ldots \ldots \ldots \ldots \ldots \ldots \ldots$ & $66.6(0.8)$ & $1.17(1.08-1.28)$ & $65.2(0.8)$ & $1.37(1.25-1.50)$ & $39.2(0.9)$ & $1.28(1.12-1.46)$ & $15.8(0.6)$ & $0.56(0.45-0.69)$ \\
\hline \multicolumn{9}{|l|}{ Physical activity } \\
\hline Any.... & $71.9(1.0)$ & $1.14(1.10-1.18)$ & $70.5(1.0)$ & $1.19(1.15-1.24)$ & $40.9(1.0)$ & $1.15(1.07-1.23)$ & $12.6(0.8)$ & $0.63(0.55-0.73)$ \\
\hline None... & $63.6(0.9)$ & $1.00(\ldots)$ & $58.7(0.9)$ & $1.00(\ldots)$ & $35.9(0.9)$ & $1.00(\ldots)$ & $18.9(0.7)$ & $1.00(\ldots)$ \\
\hline \multicolumn{9}{|l|}{ Flu vaccination } \\
\hline Yes $\ldots \ldots \ldots \ldots \ldots \ldots \ldots$ & $73.5(0.7)$ & $1.38(1.31-1.45)$ & $69.6(0.7)$ & $1.40(1.33-1.47)$ & $40.6(0.8)$ & $1.23(1.14-1.33)$ & $11.6(0.6)$ & $0.40(0.36-0.46)$ \\
\hline No.................... & $53.1(1.2)$ & $1.00(\ldots)$ & $49.2(1.2)$ & $1.00(\ldots)$ & $32.7(1.1)$ & $1.00(\ldots)$ & $27.5(1.1)$ & $1.00(\ldots)$ \\
\hline \multicolumn{9}{|l|}{ Received health care at least 10 times } \\
\hline 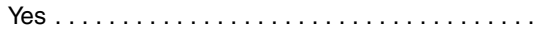 & $70.4(1.4)$ & $1.06(1.01-1.10)$ & $62.4(1.5)$ & $0.98(0.94-1.04)$ & $36.5(1.5)$ & $0.95(0.87-1.03)$ & $14.5(1.1)$ & $0.87(0.74-1.02)$ \\
\hline 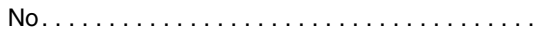 & $66.4(0.7)$ & $1.00(\ldots)$ & $63.5(0.7)$ & $1.00(\ldots)$ & $38.5(0.8)$ & $1.00(\ldots)$ & $16.8(0.6)$ & $1.00(\ldots)$ \\
\hline
\end{tabular}

Category not applicable.

'Estimates were calculated using National Health Interview Survey (NHIS) Sample Adult weights and adjusted for the complex design of NHIS.

${ }^{2}$ Age-adjusted using three age groups (65-74, 75-84, and 85 and over) and the projected 2000 U.S. population as the standard population.

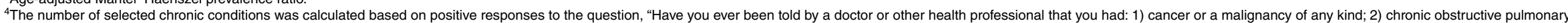

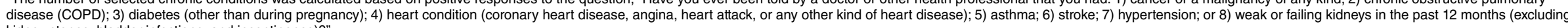
kidney stones, bladder infections, and incontinence)?"

NOTE:MSA is metropolitan statistical area.

SOURCE: National Center for Health Statistics, National Health Interview Survey, 2015 and 2018 


\section{U.S. DEPARTMENT OF HEALTH \& HUMAN SERVICES}

FIRST CLASS MAIL

POSTAGE \& FEES PAID

$\mathrm{CDC} / \mathrm{NCHS}$

Centers for Disease Control and Prevention

PERMIT NO. G-284

National Center for Health Statistics

3311 Toledo Road, Room 4551, MS P08

Hyattsville, MD 20782-2064

OFFICIAL BUSINESS

PENALTY FOR PRIVATE USE, $\$ 300$

For more NCHS NHSRs, visit:

https://www.cdc.gov/nchs/products/nhsr.htm.

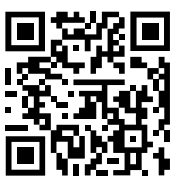

\section{Suggested citation}

Gorina Y, Elgaddal N. Patterns of

mammography, pap smear, and colorectal cancer screening services among women aged 45 and over. National Health Statistics Reports; no 157. Hyattsville, MD: National Center for Health Statistics. 2021. DOI: https://dx.doi. org/10.15620/cdc:105533.

\section{Copyright information}

All material appearing in this report is in the public domain and may be reproduced or copied without permission; citation as to source, however, is appreciated.
National Center for Health Statistics

Brian C. Moyer, Ph.D., Director

Amy M. Branum, Ph.D., Acting Associate Director for Science

Division of Analysis and Epidemiology

Irma E. Arispe, Ph.D., Director

Kevin C. Heslin, Ph.D., Associate Director for Science

For e-mail updates on NCHS publication releases, subscribe online at: https://www.cdc.gov/nchs/email-updates.htm For questions or general information about NCHS: Tel: 1-800-CDC-INFO (1-800-232-4636) • TTY: 1-888-232-6348 Internet: https://www.cdc.gov/nchs • Online request form: https://www.cdc.gov/info • CS324180 